\title{
Localization of the Human Homolog of the Yeast Cell Division Control 27 Gene (CDC27) Proximal to ITGB3 on Human Chromosome 17q21.3
}

\author{
Peggy P. Ho, ${ }^{1,6}$ Fergus J. Couch, ${ }^{2}$ Lawrence C. Brody, ${ }^{3}$ Kenneth J. Abel, ${ }^{4}$ Michael Boehnke, ${ }^{5}$ \\ Tempie H. Shearon, ${ }^{5}$ Settara C. Chandrasekharappa, ${ }^{3}$ Francis S. Collins, ${ }^{3}$ \\ and Barbara L. Weber ${ }^{2}$

\begin{abstract}
${ }^{1}$ Wayne State University, Department of Immunology and Microbiology, 540 East Canfield, Detroit, Michigan 48201; ${ }^{2}$ University of Pennsylvania, Department of Intemal Medicine, Philadelphia, Pennsylvania 19104; ${ }^{3}$ The Laboratory of Gene Transfer, National Center for Human Genome Research, National Institutes of Health, Bethesda, Maryland 20892; and University of Michigan, Departments of ${ }^{4}$ Human Genetics and ${ }^{5}$ Biostatistics, Ann Arbor, Michigan 48109.
\end{abstract}

Received 4 August 1995-Final 13 September 1995

\begin{abstract}
The human homolog of the Saccharomyces cerevisiae cell division control 27 gene (CDC27) was mapped to human chromosome 17q12-q21 using a panel of human/rodent somatic cell hybrids and localized distal to the breast cancer susceptibility gene, BRCA1, using a panel of radiation hybrids. The radiation hybrid panel indicates that the most likely position of human CDC27 on human chromosome 17 is between the marker D17S409 and the beta 3 subunit of integrin (ITGB3). Further confirmation of this localization comes from the sequence tagged site (STS) mapping of human CDC27 to the same yeast artificial chromosomes (YACs) positive for ITGB3. The estimated distance between ITGB3 and human CDC27 is less than $600 \mathrm{~kb}$.
\end{abstract}

\section{INTRODUCTION}

Saccharomyces cerevisiae CDC27 is a member of the Tetratrico Peptide Repeat (TPR) gene family which includes Aspergillus nidulans BimA and Schizosaccharomyces pombe nuc2 $2^{+}$(1). Members of this gene family contain multiple tandem repeats of a 34 amino acid (a.a.) sequence. TPR genes are involved in different stages of the yeast cell division cycle. $C D C 27$ gene function is required in the late $\mathrm{G} 2$ phase, prior to the initiation of mitosis in yeast (2). Using an expressed sequence tag data base search, the human homolog to $S$. cerevisiae $C D C 27$ $(\mathrm{CDC} 27 \mathrm{Hs})^{7}$ was recently cloned and found to encode an 823 a.a. protein with $45 \%$ homology to the 350 a.a. C-terminal TPR block and $30 \%$ homology to the 250 a.a. $\mathrm{N}$-terminal TPR (1). CDC27 was subsequently mapped to human chromosome 17 by PCR assay of a panel of somatic cell hybrids, each hybrid containing a single human chromosome on a rodent background. $C D C 27$ was also localized to mouse chromosome 11 by hybridization of $C D C 27 H s$ to Southern blots of a mouse interspecific backcross panel. By inference from the

\footnotetext{
${ }^{6}$ To whom correspondence should be addressed.

${ }^{7}$ The accepted GDB nomenclature for the human gene is $C D C 27$, but we will refer to it as $C D C 27 H s$ hereafter to distinguish it from the $S$. cerevisiae $C D C 27$ gene.
} 
mouse mapping data, $C D C 27 H s$ was predicted to map between human chromosome $17 \mathrm{q} 21-24$, in a region bounded by the $E R B B 2$ (the erbB2 proto-oncogene) and the $P R K C A$ (protein kinase C enzyme A) genes (1).

In the present study, we confirm the inferred position of CDC27Hs made by Tugendreich et al., and refine its localization proximal to $I T G B 3$ on human chromosome $17 q 21.3$ by PCR analysis of somatic cell hybrids, radiation hybrids, and yeast artificial chromosomes.

\section{MATERIALS AND METHODS}

DNA Templates. The human chromosome 17 radiation hybrid panel (3) and the human/rodent somatic cell hybrid panel (4-8) used in this study have been reported elsewhere. Human, mouse, rat, and hamster genomic DNAs were used as controls. YAC A144B1 was obtained from the Washington University YAC Library; YACs 767G11 and 784C7 were obtained from the CEPH YAC Library.

PCR Conditions. CDC27Hs STS primer sequences were 5'-ATGACACACAACTTCAT-3', corresponding to bases 2490-2506 of the open reading frame, and 5'-CACGTCAGCACTAGTCA-3', corresponding to bases $2564-2580$ of the $3^{\prime}$ untranslated region (1). PCR was carried out in $25-\mu \mathrm{l}$ reactions containing $10 \mathrm{mM}$ TrisHCL, pH 8.3, $1.5 \mathrm{mM} \mathrm{MgCl} 2,50 \mathrm{mM} \mathrm{KCl}$, $200 \mu \mathrm{M}$ dNTPs, $1.0 \mu \mathrm{M}$ primers, 1 unit Taq DNA polymerase (BMB), and $125 \mathrm{ng}$ hybrid DNA. PCR reactions were performed on a PTC-60 Programmable Thermal Controller (MJ Research Inc.) utilizing the Touchdown PCR program which consisted of $1 \mathrm{~min}$ at $94^{\circ} \mathrm{C} ; 20$ cycles of $30 \mathrm{sec}$ at $92^{\circ} \mathrm{C}, 40 \mathrm{sec}$ at $68^{\circ} \mathrm{C}\left(-0.5^{\circ} \mathrm{C}\right.$ per cycle); then 20 cycles of 30 sec at $92^{\circ} \mathrm{C}, 40 \mathrm{sec}$ at $58^{\circ} \mathrm{C}(+1 \mathrm{sec}$ per cycle $)$. The expected product size for $C D C 27 H s$ was $90 \mathrm{bp}$.

\section{RESULTS AND DISCUSSION}

We confirmed that $C D C 27 H s$ mapped to human chromosome $17 q 12-q 21$ by utilizing a panel of human/rodent somatic cell hybrids. $C D C 27 H s$ sequence tagged site (STS) primers specific for the terminal codons of the open reading frame (bases 2490-2506) and for the $3^{\prime}$ untranslated region (bases 2564-2580) (1), were used to PCR amplify the human/rodent somatic cell hybrid panel. The panel consisted of: the human/rat hybrid 7AE4 (5) containing human chromosome 17 only; the human/mouse hybrid NF13 (6) containing human chromosome 17q11.2-qter with the breakpoint at the NF1 (neurofibromatosis type 1) locus; the human/mouse hybrid P12.3B (7) containing human chromosome $17 q 12-p t e r$ with a breakpoint at the retinoic acid receptor $\alpha$ subunit locus (RARA) (7, 8); and the human/ hamster UMHG-17/1 hybrid (4) containing human chromosome $17 \mathrm{q} 22$-qter. The STS was detected in hybrids 7AE4 and NF13 but not in $\mathrm{P} 12.3 \mathrm{~B}$ and $\mathrm{UMHG}-17 / 1$, suggesting that $C D C 27 H s$ lies distal to the $R A R A$ gene but proximal to $17 \mathrm{q} 22$ (see Figure 1A).

To further refine the localization of CDC27Hs, a human chromosome 17 radiation hybrid $(\mathrm{RH})$ panel characterized with genetic markers from $17 q 12-q 23$ (3), was typed with the STS. The entire radiation hybrid panel was screened in duplicate (see Table 1). Thirteen hybrids were considered to be daughter clones (3); therefore, multipoint analysis of the $\mathrm{RH}$ data (9) was performed on the 63 clearly independent hybrids. The most likely position for $C D C 27 H s$ on the 1000:1 framework radiation hybrid map of $17 \mathrm{q} 12-\mathrm{q} 21$ is between $M T B T 1$ (microtubule (beta) associated protein tau 1) and $I T G B 3$ (integrin, beta 3, also known as GP3A), with an estimated distance of 30 $\mathrm{cR}(8000)$ between $M T B T 1$ and $C D C 27 H s$, and $7 \mathrm{cR}(8000)$ between $C D C 27 H s$ and ITGB3 (see Figure 1A). The centiray (cR) is utilized as the unit of distance on the 


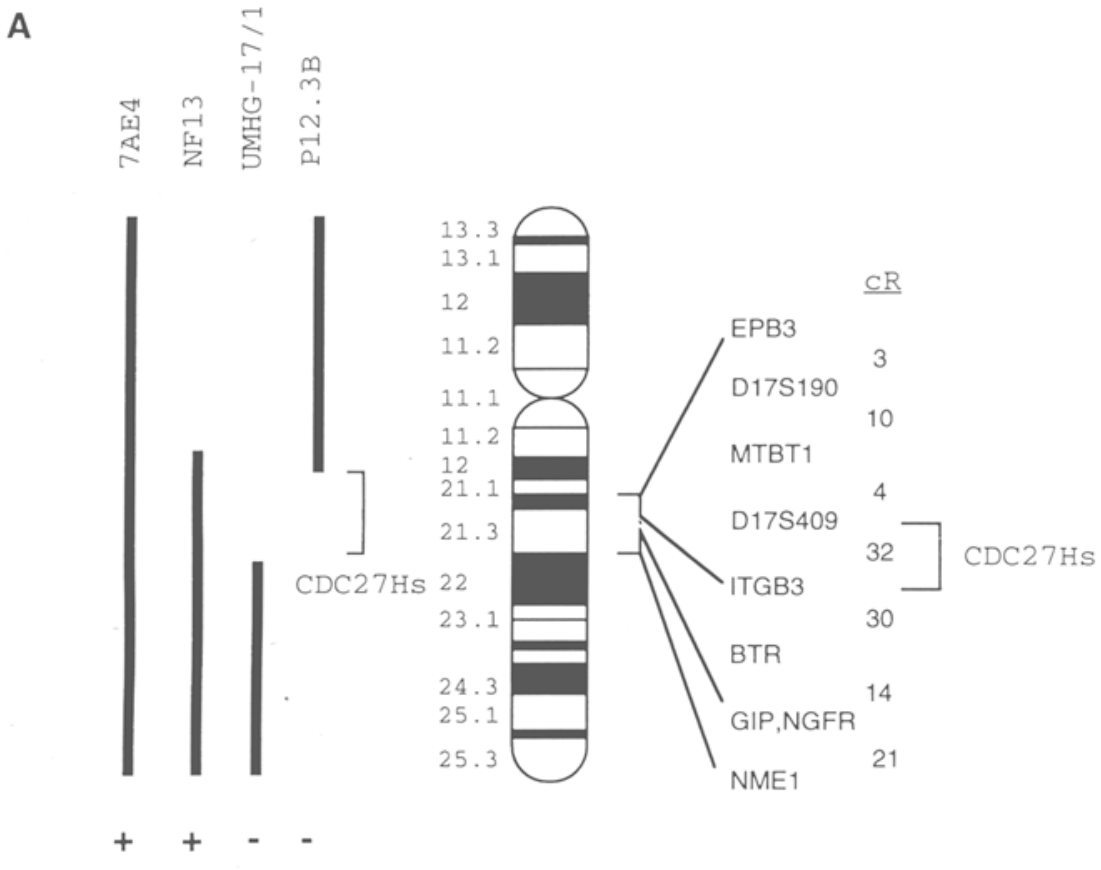

B

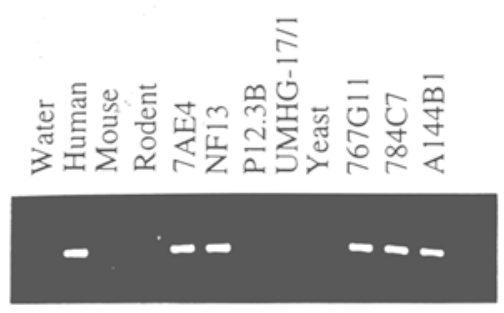

Fig. 1. Mapping of $C D C 27 H s$ to human chromosome 17q12-q21. (A) Regional localization of $C D C 27 H s$ on human chromosome $17 \mathrm{q}$ by somatic cell hybrid analysis. Vertical bars to the left of chromosome 17 indicate the regions of chromosome 17 retained in the human/rodent somatic cell hybrids. The bracket depicts the region in which $C D C 27 H s$ is assigned. Localization of $C D C 27 H s$ by radiation hybrid analysis is illustrated to the right of chromosome 17. Previously mapped genes from the $17 q 12-q 21$ region along with intervening distances in centirays, $c R(8000)$ are shown. The bracket depicts the most likely placement of $C D C 27 H s$. (B) Ethidium-bromide-stained $2 \%$ agarose gel analysis of $C D C 27 H s$ STS PCR amplified human/rodent somatic cell hybrid and YAC DNAs. Lane 1 contains results of PCR amplification from water. Lanes 2-4 contain PCR results from human, mouse, and rodent (combined rat and hamster) genomic DNA. Lanes 5-8 contain PCR amplified human/rodent clones 7AE4, NF13, P12.3B, and UMHG-17/1 respectively. Lanes $9,10,11$, and 12 contain PCR results from AB1380 yeast genomic DNA, YAC 767G11, YAC 784C7, and YAC A144B1.

radiation hybrid map, where $100 \mathrm{cR}(8000)$ corresponds to one expected break per hybrid after 8000 rads of exposure (3). The next most likely placement of $C D C 27 H s$ is between ITGB3 and BTR (BT474 transcribed rearrangement) and has maximum likelihood 30 fold less than the MTBT1-ITGB3 localiza- tion. On the comprehensive RH map, which shows the most likely order for all typed markers, $C D C 27 H s$ is placed with greatest likelihood between the marker D17S409 and $I T G B 3$, with an estimated distance of 25 cR(8000) between $D 175409$ and $C D C 27 H s$ and $7 \mathrm{cR}(8000)$ between $C D C 27 H s$ and 
Table 1. Retention Scores for $C D C 27 H s$ on the Chromosome 17q12-q21 Radiation Hybrid Panel ${ }^{a}$

\begin{tabular}{cccccccc}
\hline RH & CDC27Hs & RH & CDC27Hs & RH & CDC27Hs & RH & CDC27Hs \\
\hline 1 & - & $18 \mathrm{~b}$ & - & 31 & - & 66 & - \\
3 & - & $18 \mathrm{c}$ & + & $32 \mathrm{~b}$ & + & 67 & + \\
4 & - & 19 & - & $32 \mathrm{c}$ & + & 68 & + \\
5 & - & $20 \mathrm{a}$ & - & 37 & - & 69 & + \\
6 & - & $20 \mathrm{~b}$ & - & $42 \mathrm{a}$ & - & 70 & + \\
7 & - & $20 \mathrm{c}$ & - & $42 \mathrm{~b}$ & - & 71 & + \\
$8 \mathrm{a}$ & - & $21 \mathrm{a}$ & - & 43 & - & $72 \mathrm{~b}$ & - \\
$8 \mathrm{~b}$ & + & $21 \mathrm{~b}$ & - & $44 \mathrm{a}$ & + & $72 \mathrm{c}$ & - \\
$8 \mathrm{c}$ & - & $22 \mathrm{a}$ & - & $44 \mathrm{~b}$ & + & 73 & - \\
9 & + & $22 \mathrm{~b}$ & + & 45 & - & $74 \mathrm{~b}$ & + \\
$10 \mathrm{a}$ & - & $22 \mathrm{~d}$ & + & $49 \mathrm{~b}$ & + & $74 \mathrm{c}$ & + \\
$10 \mathrm{~b}$ & - & 23 & + & $49 \mathrm{~d}$ & - & 75 & + \\
11 & + & 24 & - & 50 & + & $76 \mathrm{a}$ & - \\
12 & - & $25 \mathrm{a}$ & + & 54 & - & $76 \mathrm{~b}$ & - \\
13 & - & $25 \mathrm{~b}$ & + & 55 & + & $76 \mathrm{c}$ & - \\
15 & - & 26 & + & 56 & + & $76 \mathrm{~d}$ & - \\
$16 \mathrm{a}$ & - & $27 \mathrm{a}$ & + & 57 & + & & \\
$16 \mathrm{~b}$ & - & $27 \mathrm{c}$ & - & 61 & + & & \\
17 & - & 28 & - & $64 \mathrm{a}$ & - & & \\
$18 \mathrm{a}$ & - & 29 & - & $64 \mathrm{~b}$ & - & & \\
\hline
\end{tabular}

${ }^{a}$ Note: A hybrid scored (+) indicates the presence of the $C D C 27 H s$ STS in that hybrid. A hybrid scored ( - ) indicates the absence of the CDC27Hs STS. Hybrid scores can be matched to previously published retention scores for other markers in the $17 \mathrm{q} 12$-q21 region (3).

ITGB3. Using the relationship of $50-90 \mathrm{~kb} / 1$ $\mathrm{cR}(8000)$ (3), $C D C 27 H s$ is estimated to be $1250-2250 \mathrm{~kb}$ distal to the marker D17S409 and $350-630 \mathrm{~kb}$ proximal to ITGB3 (see Figure 1A).

In order to further assess the placement of $C D C 27 H s$ relative to ITGB3, thirty-three yeast artificial chromosomes (YACs) from the 17q12-q21 region were screened with the $C D C 27 H s$ STS primers. YAC A144B1 from the Washington University YAC Library, and YACs $767 \mathrm{G} 11$ and $784 \mathrm{C} 7$ from the CEPH YAC Library, were positive by PCR with the $C D C 27 H s$ STS primers (see Figure 1B). All three YACs were also positive for ITGB3 (10, data not shown). YAC sizes for A144B1 and 767G11 are estimated to be 600 $\mathrm{kb}$ and $1380 \mathrm{~kb}$, respectively. These results further indicate the proximity of $\mathrm{CDC} 27 \mathrm{Hs}$ to ITGB3, which has been placed on chromosome 17q21.3 (as reported in the Genome Data Base).

In conclusion, several methods have been utilized to localize $C D C 27 H s$ between the marker D17S409 and ITGB3 on human chromosome 17q12-q21, placing it distal to the breast cancer susceptibility gene, $B R C A 1$ $(11,12)$. Results from the radiation hybrid panel suggest that $C D C 27 H s$ is $350-630 \mathrm{~kb}$ proximal to ITGB3. The presence of both $C D C 27 H s$ and ITGB3 on YACs A144B1, $767 \mathrm{G} 11$, and $784 \mathrm{C} 7$ is consistent with these distance estimates. The precise localization of this gene should prove useful for future physical mapping and transcript mapping of this region of human chromosome 17.

\section{ACKNOWLEDGMENTS}

We thank Stuart Tugendreich and Philip Heiter for their generosity in providing the $C D C 27 H s$ primers. This research was supported by NIH R01 grants CA-57601 and CA-61231 to B.W., and HG-60209 to M.B.

\section{LITERATURE CITED}

1. Tugendreich, S., Boguski, M.S., Seldin, M.S., and Hieter, P. (1993). Proc. Natl. Acad. Sci. USA 90:10031-10035. 
2. Hughes, D.A., MacNeill, S.A., and Fantes, P.A. (1992). Mol. Gen. Genet. 231:401-410.

3. Abel, K.J., Boehnke, M., Prahalad, M., Ho, P., Flejter, W.L., Watkins, M., Vanderstoep, J., Chandrasekharappa, S.C., Collins, F.S., Glover, T.W., and Weber, B.L. (1993). Genomics 17:632641.

4. Flejter, W.L., Watkins, M., Abel, K.J., Chandrasekharappa, S.C., Weber, B.L., Collins, F.S., and Glover, T.W. (1993). Cytogenet. Cell Genet. 64:222-223.

5. Leach, R.J., Thayer, M.J., Schafer, A.J., and Fournier, R.E.K. (1989). Genomics 5:167-176.

6. Menon, A.G., Ledbetter, D.H., Rich, D.C., Seizinger, B.R., Rouleau, G.A., Michels, V.F., Schmidt, M.A., Dewald, G., Dalla Torre, C.M., Haines, J., and Gusella, J.F. (1989). Genomics 5:245-249.

7. van Tuinen, P., Rich, D.C., Sumers, K.M., and Ledbetter, D.H. (1987). Genomics 1:374-381.

8. Borrow, J., Goddard, A.D., Sheer, D., and Solomon, E. (1990). Science 249:1577-1580.

9. Boehnke, M., Lange, K., and Cox, D.R. (1991). Am. J. Hum. Genet. 49:1174-1188.

10. Flejter, W.L., Bancroft, C.L., Guo, S-W, Lynch, E.D., Boehnke, M., Chandrasekharappa, S., Hayes,
S., Collins, F.S., Weber, B.L., and Glover, T.W. (1993). Genomics 17:624-631.

11. Futreal, P.A., Liu, Q., Shattuck-Eidens, D., Cochran, C., Harshman, K., Tavtigian, S., Bennett, L.M., Haugen-Strano, A., Swensen, J., Miki, Y., Eddington, K., McClure, M., Frye, C., WeaverFeldhaus, J., Ding, W., Gholami, Z., Soderkvist, P., Terry, L., Jhanwar, S., Berchuck, A., Iglehart, J.D., Marks, J., Ballinger, D.G., Barrett, J.C., Skolnick, M.H., Kamb, A., Wiseman, R. (1994). Science 266:120-122.

12. Miki, Y., Swensen, J., Shattuck-Eidens, D., Futreal, P.A., Harshman, K., Tavtigian, S., Liu, Q., Cochran, C., Bennett, L.M., Ding, W., Bell, R., Rosenthal, J., Hussey, C., Tran, T., McClure, M., Frye, C., Hattier, T., Phelps, R., Haugen-Strano, A., Katcher, H., Yakumo, K., Gholami, Z., Shaffer, D., Stone, S., Bayer, S., Wray, C., Bogen, R., Dayananth, P., Ward, J., Tonin, P., Narod, S., Bristow, P.K., Norris, F.H., Helvering, L., Morrison, P., Rosteck, P., Lai, M., Barrett, J.C., Lewis, C., Neuhausen, S., Cannon-Albright, L., Goldgar, D., Wiseman, R., Kamb, A., Skolnick, M.H. (1994). Science 266:66-71. 